\title{
OKULUM VE ÖĞRETMENIM HAKKINDA NE DÜŞÜNÜYORUM?
}

\author{
Ayşe ÖZTÜRK SAMUR ${ }^{1}$
}

GöZde INAL KIZILTEPE²

Atıf/O: Samur, Ayşe Öztürk ve Kizlltepe, Gözde İnal (2017). Okulum ve Öğretmenim Hakkında Ne Düşünüyorum?. Hitit Üniversitesi Sosyal Bilimler Enstitüsü Dergisi, Yıl 10, Sayı 2, Aralı 2017, ss.1257-1276

Özet: Araştırma, 60-72 aylık çocukların okula ilişkin duyguları, öğretmenleri ile ilgili düşüncüleri ve akademik yeterliklerine ilişkin algıların belirlemek amacıyla gerçekleştirilmiştir. Bu doğrultuda araştırmada, veri toplama tekniği olarak hem nicel hem nitel boyutları içeren karma yöntem kullanılmıştır. Araştırmanın çalışma grubunu, Aydin ili merkez ilçede yer alan okul öncesi eğitim kurumlarina devam eden çocukların içinden tesadüfi örnekleme yöntemi ile seçilen 60-72 aylık 250 çocuk oluşturmaktadır. Araştırmanin nicel boyutunda veriler Valeski ve Stipek (2001) tarafindan geliştirilen "Okul Hakkındaki Duygularım” ölçeği kullanılarak toplanmıştır. Araştırmanin nitel boyutunda ise 60-72 aylık 30 çocuk ile yar yapilandırlmış görüşmeler yapılmıştır. Araştırmanin sonucunda, nicel olarak elde edilen verilerin, nitel olarak elde edilen veriler tarafindan da desteklendiği çocukların çoğunluğunun; okula ve öğretmene ilişkin duygu ve düşüncelerinin yüksek düzeyde olduğu, matematiğe ilişskin algılarının orta düzeyde olduğu, okuma yazmaya ilişkin algılarının ise düşük düzeyde olduğu tespit edilmiştir.

Anahtar Sözcük: Okul Öncesi Eğitim, Öğretmen, Okul.

Makale Geliş Tarihi: 06.16.2017/ Makale Kabul Tarihi: 11.08.2017

1 Yrd. Doç. Dr., Adnan Menderes Üniversitesi, Eğitim Fakültesi, Temel Eğitim Bölümü, e-posta: ayseozturksamur@yahoo.com

2 Yrd. Doç. Dr., Adnan Menderes Üniversitesi, Eğitim Fakültesi, Temel Eğitim Bölümü, e-posta: ggozdeinal@gmail.com 


\section{What I Think About School And Teacher?}

Citation/@: Samur, Ayşe Öztürk ve Kizlltepe, Gözde İnal (2017). What I Think About School And Teacher?, Hitit University Journal of Social Sciences Institute, Year 10, Issue 2, December 2017, pp.1257-1276

Abstract: In the study, it was aimed to determine the perceptions of 60-72 month old children, about their feelings towards the school, their thoughts about their teachers and their academic competencies. In accordance with the aim while collecting data, a mixed method which includes both quantitative and qualitative techniques was used. The study group of the study consisted of 250 children aged 60-72 months who were selected by random sampling method among the children attending pre-primary education institutions located in central province of Aydin province. In the quantitative dimension of the study, data was collected using the "Feelings about School" scale developed by Valeski and Stipek (2001). In the qualitative dimension of the survey, semi-structured interviews were conducted with 30 children aged 60-72 months. At the end of the study, it was identified that quantitatively collected data supported the qualitatively collected data and the majority of children' thoughts and feelings about their teachers and school were very high; their perception about mathematics was average and their perceptions about reading-writing was low.

Keywords: Preschool Education, Teacher, School.

\section{GİṘŞ}

Çocukların yaşantısında aileden sonra gelen en önemli gelişimsel sistem okuldur. Okul, sosyalleşme sürecinde, ilk temel toplumsal kurum olma özelliği taşır (Bronfenbrenner ve Morris, 2006; Meşeci, 2008). İlk y1llarda ailesi ile sosyal ilişkiler kuran çocuk, okul öncesi eğitimle birlikte sosyal ilişki ağını genişleterek daha çok kişiyle etkileşime geçmekte ve buna bağlı olarak sosyal çevresi, öğretmen ve akranlarıyla genişlemektedir (Uz Baş, 2003; Ekinci-Vural, 2006; Karaca, Gündüz ve Aral, 2011).

Okul; kendine özgü kuralları, yerine getirilmesi gereken görev ve sorumlulukları ve yeni yaşamsal deneyimleri içeren evden farklı bir sosyal çevredir. Bu süreçte, çocuklar yeni bir bina ve sınıf ortamına uyum sağlarken, aynı zamanda öğretmenin beklentilerini nasıl karş1layacağını, akran grubuna kendini nasıl kabul ettireceğini öğrenmek ve akademik becerilerini geliştirmek zorundadır (Fabian, 2000; Koomen, Verschueren ve Thijs, 2006; Ladd, Herald ve Kochel, 2006). Okula karşı olumlu tutum içinde olan ve okulu seven çocuklar, etkinliklere katılım konusunda okula karşı negatif tutum içinde olan ve alg1 düzeyleri daha düşük olan çocuklara göre daha hevesli ve isteklidirler (Valeski 
ve Stipek, 2001). Bununla birlikte öğretmen ile kurulan yakın ilişki de çocuğun okul ve öğretmeni hakkında olumlu duygu ve düşüncelerinin oluşmasını sağlamakta ve çocuğun okula uyumunu kolaylaştırmaktadır (Pianta ve Stuhlman, 2004). Aynı zamanda öğretmen ile kurulan olumlu ve yakın ilişki, çocuklar için güven ve sosyal destek kaynağı olmakta, (Gregoriadis ve Grammatikopoulos, 2013), çocukların diğerleri ile ilişki kurmasını sağlamakta, sınıf içindeki öğrenme firsatlarından yararlanabilme olanaklarını artırarak akademik başarılarını desteklemektedir (Howes, Phillipsen ve Peisner-Feinberg, 2000; Hughes ve Kwok, 2006; Dotterer ve Lowe, 2011). Yapilan araştırmalar, okul öncesi dönemde çevresindeki yetişkinlerle zengin bir iletişim deneyimi olan çocukların, sonraki okul yıllarında da akademik açıdan daha başarılı olduklarını gösterirken (Birch ve Ladd, 1997; Burchinal, Peisner-Feinberg, Pianta ve Howes, 2002), katı bir şekilde yapılanmış öğretmen egemen eğitim ortamlarının ise, çocukların kendi akademik yetkinliklerine ilişkin negatif bir algı oluşturmasına neden olduğunu ortaya koymaktadır (Stipek, Feiler, Daniels ve Milburn,1995; Stipek, 2001; Hughes ve Kwok, 2007). Görüldüğü gibi öğretmen çocuk arasındaki yakın ilişki çocuğun hem okula ilişkin duygularını, hem de akademik becerilere ilişkin algısını etkilemektedir. Bununla birlikte okul öncesi dönem çocuklarının akademik yetkinliklerinin okula ve öğretmene karşı tutumları üzerindeki etkisini inceleyen sınırlı sayıda araştırma vardır. Bu araştırmalarda, matematik ve okuma yazma becerileri açısından başarılı olan okul öncesi dönem çocuklarının, okullarını daha fazla sevdikleri belirlenmiştir. Ayrıca bu çocukların matematik ve okuma yazma becerileri açısından daha başarısız olan akranlarına göre öğretmenleri ile daha iyi anlaştıkları ortaya konulmuştur (Ramey, Lanzi, Phillips ve Ramey, 1998; Ladd, Birch ve Buhs, 1999; Valeski ve Stipek, 2001). Bununla birlikte, akademik açıdan daha başarılı olan çocukların okul ve öğretmenlerine karşı başarısız olan çocuklara göre daha pozitif davranışlar sergiledikleri de belirlenmiştir (Ramey, Lanzi, Phillips ve Ramey, 1998; Ladd, Buhs ve Seid, 2000).

Tüm bulgular göstermektedir ki; akademik ve sosyal beceriler okul öncesi dönemde kazanılmaya başlandığından, bu dönemde çocukların okul, öğretmen ve akademik yetkinliklerine ilişkin duygu ve tutumlarının incelenmesi büyük önem taşımaktadır. Ancak konuya ilişkin araştırmalar incelendiğinde, 
çocukların bakış açısına dayanan çalışmaların sınırlı sayıda ve çoğunlukla öğretmen-çocuk ilişkisini değerlendirmeye yönelik olduğu belirlenmiştir. Öğretmen-çocuk ilişkisinin beş-altı yaş çocuklarının bakış açısına göre değerlendirildiği araştırmalarda Küçük Çocuklar Tarafından Öğretmen Desteğinin Değerlendirilmesi Ölçeği (Young Children's Appraisals of Teacher Support/Y-CATS) ve Ailem ve Arkadaşlarım Çocuk Formunun (My Family and Friends-Child /MFF-C) kullanıldığı, ayrıca çocukların kendi ve öğretmenini çizdiği resimler yoluyla değerlendirmeler yapıldığı (Mantzicopoulos ve NeuharthPritchett, 2003; Harrison, Clarke ve Ungerer, 2007; Murray, Murray ve Waas, 2008) görülmektedir. Okul öncesi ve ilkokul birinci sınıf çocuklarının, öğretmençocuk ilişkisi ile birlikte, okula karşı tutumunu ve akademik yetkinliklerine ilişkin algısını değerlendirmeye yönelik olarak Valeski ve Stipek (2001) tarafından geliştirilen Okul Hakkındaki Duygular Ölçeği (Feelings about School/FAS) bulunmaktadır. Görüldüğü gibi, literatürde çocuk bakış açısıyla konunun ele alındığı sınırlı çalışma olmasının yanı sıra ülkemizde ise konu ile ilgili yapılmış geniş kapsamlı bir çalışmaya rastlanılmamıştır. Oysa okul, öğretmen ve akademik yeterlikleri ile ilgili çocukların duygu düşüncelerinin belirlenmesi, bu duygu ve düşüncelerinin altında yatan sebeplerin ve sonuçlarının anlaşılmasını sağlayacaktır. Bu noktadan hareketle bu çalışma, 60-72 aylık çocukların kendi bakış açılarından okula karşı duyguları, öğretmenleri ile ilgili düşüncüleri ve akademik yeterliklerine ilişkin algılarını nicel ve nitel boyutta belirlenmesi amacıyla gerçekleştirilmiştir. Bu amaç doğrultusunda aşağıdaki sorulara yanıt aranmıştır.

1. 60-72 aylık çocukların okula ilişkin duyguları hangi düzeydedir?

2. 60-72 aylık çocukların öğretmenleri ile ilgili düşüncüleri hangi düzeydedir?

3. 60-72 aylık çocukların akademik (matematik ve okuma yazma) yeterliklerine ilişkin algıları hangi düzeydedir? 


\section{YÖNTEM}

\section{A. Araştırma Deseni}

Karma yöntem yaklaşımı, sosyal bilimlerde amaçlı olarak iki ya da daha fazla analiz veya veri toplama yolunun aynı araştırmada kullanılması olarak tanımlanmaktadır. Karma yöntem yaklaşımında, nicel yöntem aracılığı ile toplanan veriler, daha çok katılımcıya ulaşılmasını sağlarken, nitel yöntemler kullanılarak elde edilen veriler ise nicel yöntemde sayılarla elde edilen verilerin daha derinlemesine incelenmesine imkân sağlar (Green, Krayder ve Mayer, 2005). Mevcut durumu sorgulayan betimsel bir araştırma olan çalışmada 60-72 aylık çocukların okula ilişkin duyguları, öğretmenleri ile ilgili düşüncüleri ve akademik yeterliklerine ilişkin algılarını belirlemek için tarama modelinden yararlanılmış, bulguları zenginleştirmek ve ulaşılan bu bulguların birbirini desteklemesini sağlamak için nicel ve nitel yöntemler çalışmada birlikte kullanılmıştır. Çalışmada öncelikle, nicel veriler elde edilmiş, ardından nicel veriler nitel verilerle desteklenmiştir.

\section{B. Çalışma Grubu}

Araştırmanın evrenini, 2016-2017 eğitim öğretim yılında Aydın ili Efeler merkez ilçesinde Milli Eğitim Bakanlı̆̆ı'na bağlı anaokulları ile ilkokulların bünyesindeki anasınıflarına devam eden 60-72 aylık çocuklar oluşturmaktadır. Araştırmanın nicel boyutunun çalışma grubu, tesadüfi örnekleme yöntemi ile belirlenen 60-72 aylık 134 kız 116 erkek olmak üzere toplam 250 çocuktan oluşmaktayken, nitel boyutunun çalışma grubu ise araştırmada kullanılan ölçeğin toplamından yüksek, orta ve düşük düzeyde puan alan 10'ar çocuk olmak üzere toplam 30 çocuktan oluşmaktadır.

\section{Veri Toplama Arac1}

Araştırmanın nicel boyutunda veri toplamak üzere, 2001 yılında Valeski ve Stipek tarafından çocukların okuma yazma ile matematik yeterliliklerine ilişkin algılarını, öğretmen ile ilgili duygularını ve okula karşı genel tutumlarını değerlendirmek amacı ile geliştirilen "Okul Hakkındaki Duygularım" (Feelings About School) ölçeği kullanılmıştır. Okul, öğretmen, matematik ve okuma yazma olmak üzere 4 boyutta toplam 12 maddeden oluşan orijinal ölçek, çocuklara 
bireysel olarak uygulanan 5'li likert tipi bir ölçektir. Orijinal ölçekte uygulayıc1, soru maddesini yönelttikten sonra çocuktan cevabını, 1'den 5'e doğru artan sütunlar üzerinde parmağ1 ile göstermesini ister. Ölçek maddeleri öncesinde, çocukların uygulamayı anlayabilmesi amacıyla örnek sorular sorulur, çocuğun anladığından emin olunduktan sonra esas ölçek maddelerine geçilir (Valeski ve Stipek, 2001).

Ölçeğin geçerlik güvenirlik çalışması kapsamında dil geçerliğini sağlamak amacıyla üç dil uzmanı tarafından maddeler Türkçe'ye çevrilmiştir. Türkçe ve İngilizce formlar arasında anlam farklılı̆̆ının olmadığı belirlenmiştir. Türk Dili uzmanı tarafından maddeler tekrar gözden geçirilerek ölçeğe son şekli verilmiştir. Ölçeğin, kapsam geçerliği ve Türk kültürüne uygunluğu için beş ayrı ögretim üyesinden her bir maddeyi amacına uygunluk ve anlaşılırlık bakımından değerlendirmeleri istenmiş, uzman görüşleri toplandıktan sonra Lawshe Tekniği dikkate alınarak analizler yapılmıştır. Lawshe tekniğine göre KGO değeri 0' a eşit ya da negatiflik içeriyorsa bu madde öncelikle elenmekte, KGO değerleri pozitif olan maddelerin anlamlılıkları test edilmektedir (Lawshe, 1975 akt: Yurdugül, 2005). Uzmanlardan gelen görüşler doğrultusunda OHD'nin KGO değeri 1 olarak bulunmuştur. Bu değere göre ölçeğin kapsam geçerliği istatiksel olarak anlamlıdır. Hazırlanan uzman görüş formunun öneri/görüş kısmına yazılan görüşler değerlendirilmiş, bu doğrultuda ölçek 5' li likert ölçekten 3' lü likert ölçeğe dönüştürülerek ölçeğe son şekli verilmiştir.

Kapsam geçerliği sonrasında, Aydın ili Efeler merkez ilçesindeki Milli Eğitim Bakanlığı'na bağlı ilkokul bünyesindeki anasınıflarına devam eden 60-72 aylık çocuklar arasından tesadüfî örnekleme yöntemi ile seçilen 30 çocuk ile yapılan ön uygulama sonucunda ölçek maddelerinin çocuklar tarafından aynı biçimde anlaşıldığ1 ve yorumlandığı görülmüsstür. Bu nedenle ön uygulamaya alınan 30 çocuk örneklem grubuna dâhil edilmiştir. Ön uygulama çalışması sonrasında ölçek belirlenen örneklem grubunda uygulanmaya hazır hale getirilmiştir.

Ölçeğin yapı geçerliliği 2015-2016 eğitim öğretim yılında Aydın ili Efeler merkez ilçesindeki Milli Eğitim Bakanlığı'na bağlı anaokulları ile ilkokulların bünyesindeki anasınıflarına devam eden 60-72 aylık 318 çocuktan (162 kız, 156 erkek) toplanan veriler üzerinde yapılmıştır. Ölçeğin dört faktör ve 12 maddelik yapısının doğrulanıp doğrulanmadığını değerlendirmek amacıyla birinci ve ikinci 
düzey doğrulayıcı faktör analizi (DFA) uygulanmıştır. İkinci düzey faktör analizinin yapılma amacı, üst yapının doğrulanıp doğrulanmadığını belirleyerek ölçekten toplam puan alınıp alınmayacağını incelemektir. Uygulanan ilk DFA'da istatistiksel olarak anlamlı olmayan t değerine sahip madde bulunmamıştır. Şekil 1'de path diyagramı verilmiştir.

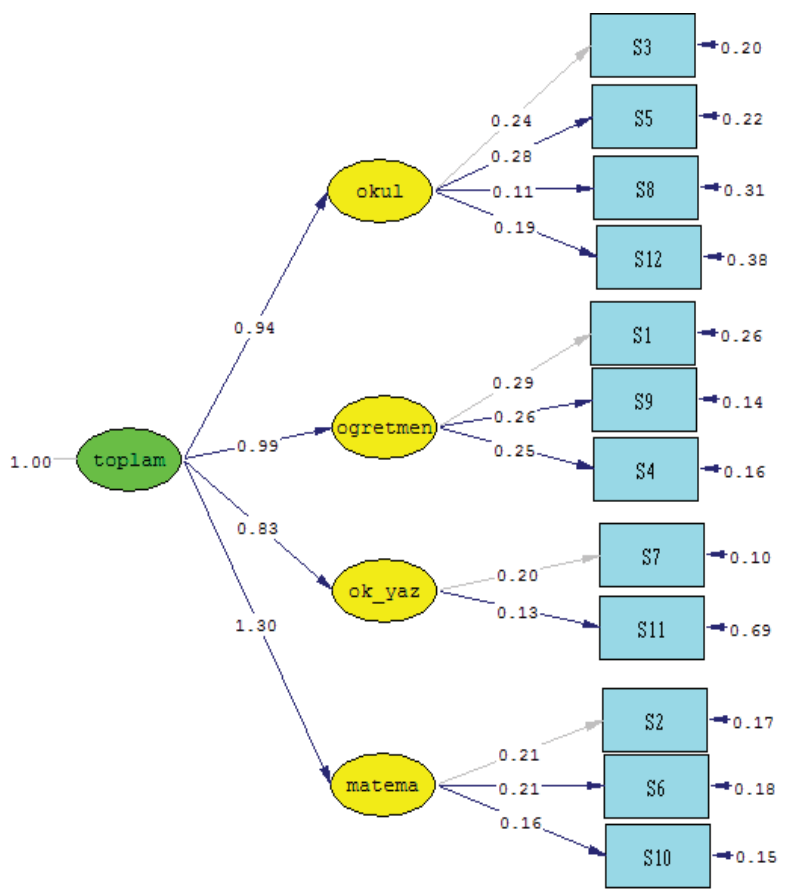

Şekil 1. Okul Hakkındaki Duygularım Ölçeğine Ait Path Diagramı

Şekil 1 incelendiğinde, ölçeğin 4 boyut ve 12 maddeden oluştuğu görülmektedir. Uyum indeksleri $\mathrm{x} 2=104.16, \mathrm{X} 2 / \mathrm{sd}=2.03, \quad \mathrm{RMSEA}=0.058, \quad \mathrm{CFI}=0.93$, NNFI=0.91, NFI=0.88 ve IFI=0.93 olarak tespit edilmiştir. Ölçeğin faktöryel yapısını gösteren modelin gözlenen değişkenleriyle faktörleri arasındaki ilişkiyi gösteren katsayılar incelendiğinde, tüm katsayıların yüksek düzeyde olduğu tespit edilmiştir. DFA ile hesaplanan uyum istatistikleri dikkate alındığında, ölçeğin daha önce belirlenen 4 faktörlü yapısının toplanan verilerle uyum 
sağladığ belirlenmiştir. Maddelere ait regresyon ve $t$ değerleri Tablo 1'de verilmiştir.

Tablo 1. DFA'ya ait Regresyon ve t Değerleri

\begin{tabular}{ccc}
\hline Maddeler & Regresyon değerleri & t değerleri \\
Madde 1 & 0.47 & 4.96 \\
Madde 2 & 0.52 & 5.95 \\
Madde 3 & 0.19 & 2.80 \\
Madde 4 & 0.30 & 4.12 \\
Madde 5 & 0.50 & 6.19 \\
Madde 6 & 0.57 & 6.89 \\
Madde 7 & 0.52 & 6.53 \\
Madde 8 & 0.54 & 7.01 \\
Madde 9 & 0.16 & 2.06 \\
Madde 10 & 0.45 & 6.62 \\
Madde 11 & 0.45 & 6.70 \\
Madde 12 & 0.38 & 5.99 \\
\hline
\end{tabular}

Tablo 1 incelendiğinde, elde edilen regresyon katsayılarının ve t değerlerinin anlamlı olduğu ( $t>1$.92) ve modelin doğrulandığı belirlenmiştir.

Ölçeğe ait 4 faktörün üst yapıyı temsil ettiğini göstermek amaciyla ikinci düzey doğrulayıcı faktör analizi yapılmıştır. Birinci düzey doğrulayıcı faktör analizinde elde edilen gizil değişkenler arasındaki ilişkiler temel alınmış ve üst düzey (ikinci düzey) değişkenin birinci düzey değişkenlerde açıkladığı varyanslar da ortaya konulmuştur. Modeldeki birinci düzey gizil değişkenler ile üst düzey (ikinci düzey) değişken arasındaki faktör yükleri (Lambda x, גx), t değerleri, ölçüm hataları (delta $\delta$ ) ve ikinci düzey değişkenin birinci düzey değişkenlerdeki açıklama oranları $\left(\mathrm{R}^{2}\right)$ Tablo 2'de verilmiştir. 
Tablo 2. İkinci Düzey DFA'ya Yönelik $\lambda x, \delta$, t ve $\mathrm{R}^{2}$ Değerleri

\begin{tabular}{llcccc}
\hline $\begin{array}{l}\text { İkinci } \\
\text { Düzey } \\
\text { Değişken }\end{array}$ & $\begin{array}{l}\text { Birinci } \\
\text { Düzey } \\
\text { Değişkenler }\end{array}$ & $\begin{array}{c}\mathbf{\lambda x} \\
\text { katsayıs1 }\end{array}$ & $\begin{array}{c}\mathbf{\delta} \\
\text { katsay1s1 } \\
\text { (Ölçüm } \\
\text { hatas1) }\end{array}$ & $\mathbf{t}$ & $\mathbf{R}^{\mathbf{2}}$ \\
\hline & $\begin{array}{l}\text { Okul boyutu } \\
\text { Tüğretmen }\end{array}$ & 0.13 & 0.12 & 7.38 & 0.88 \\
& $\begin{array}{l}\text { Ooyutu } \\
\text { boyum }\end{array}$ & 0.12 & 0.01 & 8.21 & 0.92 \\
& $\begin{array}{l}\text { Okuma } \\
\text { yazma }\end{array}$ & 0.11 & 0.31 & 7.49 & 0.69 \\
& Matematik & 0.14 & 0.68 & 9.32 & 0.95 \\
\hline
\end{tabular}

Tablo 2 incelendiğinde, üst gizil değişken ile tüm faktörler arasındaki ilişkilerin pozitif yönde ve anlamlı $(\mathrm{p}<0.05)$ olduğu görülmektedir. İkinci düzey değişkeni tarafından birinci düzey değişkenlerde açıklanan varyanslara bakıldığında, matematik boyutunun üst yapıyı en yüksek düzeyde açıkladığı tespit edilmiştir.

Ölçeğin güvenirliğinin belirlenmesinde iç tutarlılık katsayısı olan Cronbach alfa hesaplanmıştır. Okul alt boyutunun alfa değeri 0.56; öğretmen alt boyutunun alfa değeri 0.44; okuma yazma alt boyutunun alfa değeri 0.29 ve matematik alt boyutunun alfa değeri 0.35 olarak belirlenmiştir. Ölçeğin orijinal formunda ise okul alt boyutunun alfa değeri 0.52; öğretmen alt boyutunun alfa değeri 0.74 ; okuma yazma alt boyutunun alfa değeri 0.61 ve matematik alt boyutunun alfa değeri 0.68 olarak belirlenmiştir.

Araştırmanın nitel boyutunda ise veriler, araştırmacılar tarafından hazırlanan yarı yapılandırılmış görüşme formu ile toplanmıştır. Görüşme formu soruları hazırlanırken nicel verilerin toplanılmasında kullanılan OHD ölçeğinin boyutları ve maddeleri dikkate alınmıştır. Çocuklarla yapılan görüşmede, "Okulda kendini nasıl hissediyorsun? En çok ne zaman böyle hissediyorsun? Okulda en çok ne yapmayı seviyorsun? Öğretmenin hakkında ne hissediyorsun? Öğretmeninle en çok ne yapmayı seviyorsun? Sayılarla ilgili okulda neler yapıyorsun? En çok 
hangisini seviyorsun? Harflerle ilgili okulda neler yapıyorsun? En çok hangisini seviyorsun?" şeklinde sorular yöneltilmiştir.

\section{Verilerin Toplanması ve Analizi}

Ölçeğin geçerlik güvenirlik çalışmaları tamamlandıktan sonra, ölçek ve görüşme formunun uygulanabilmesi için Aydın İl Milli Eğitim Müdürlüğü’nden gerekli izinler alınmıştır. Ardından çalışma grubundaki okulların müdürleri ve okul öncesi öğretmenleri ile görüşülerek araştırmanın amacı ve veri toplama araçları hakkında bilgi verilmiştir.

Okullarda ölçeğin ve görüşme formunun uygulanması, çocukların dikkatlerini toplayıp motivasyonlarını sağlamak amacı ile eğitim ortamlarından ayrı sessiz bir odada, çocuklara uygun masa ve sandalyelerde karş11klı oturularak gerçekleştirilmiştir. Çocuklar birer birer hazırlanan odaya alınmıştır. Kısa bir sohbetle çocuğun rahatlaması sağlanmış, uygulama hakkında kısa bir bilgi verilmiştir. Ölçeğin uygulanmasına, çocuğun ölçeği öğrenmesi amacıyla örnek sorularla başlanmıştır. Uygulama esnasında kendisinden ne yapması istendiğini çocuk anladığını belirtene kadar uygulama ile ilgili verilen bilgi tekrar edilmiştir.

Ölçek uygulaması tamamlandıktan sonra ve gerekli analizler yapıldıktan sonra ölçeğin toplamından yüksek, orta ve düşük düzeyde puan alan 10'ar çocuk belirlenmiş ve ölçek uygulaması ile aynı koşullarda 30 çocuk ile yarı yapılandırılmış görüşme gerçekleştirilmiştir.

Nicel verilerin çözümlenmesinde, aritmetik ortalamalar hesaplanmış ve t testi yapılmıştır. Nitel verilerin çözümlenmesinde ise betimsel analiz tekniği kullanılmıştır. Betimsel analizde, elde edilen veriler daha önceden belirlenen temalara göre özetlenip yorumlanmakta ve görüşülen ya da gözlenen bireylerin görüşlerini ayrıntılı bir biçimde yansıtmak için doğrudan alıntılara sık sık yer verilmektedir (Yıldırım ve Şimşek, 2004). Görüşme sonuçları "okul, öğretmen, matematik ve okuma yazma" şeklinde ölçeğin boyutlarına göre gruplandırılarak bu başliklar altında değerlendirilmiştir. 


\section{BULGULAR}

$\mathrm{Bu}$ bölümde araştırma sonucunda elde edilen nicel bulgular tablo şeklinde verilmiş, nitel veriler ise araştırmaya katılanların görüşlerinden doğrudan alıntılarla özetlenmiştir.

\section{A. Nicel Bulgular}

Tablo 3’te Okul Hakkındaki Duygularım Ölçeğinin alt boyutlarına ve toplam puana ilişkin aritmetik ortalamalar verilmiştir.

Tablo 3. Okul Hakkındaki Duygularım Ölçeğinin Alt Boyut Puanlarına İlişkin Aritmetik Ortalamalar

\begin{tabular}{lllllll}
\hline & $\begin{array}{l}\text { Alt } \\
\text { Boyutlar }\end{array}$ & n & Min. & Max. & $\bar{x}$ & s \\
\hline Okul & Okul & 250 & 3.00 & 9.00 & 8.29 & 1.12 \\
Hakkındaki & Öğretmen & 250 & 3.00 & 9.00 & 7.70 & 1.28 \\
Duygularım & Matematik & 250 & 3.00 & 9.00 & 7.31 & 1.41 \\
Ölçeği & Okuma & 250 & 3.00 & 9.00 & 7.70 & 1.28 \\
\hline
\end{tabular}

Tablo 3'te aritmetik ortalamalar incelendiğinde okul alt boyutunun $\bar{x}=8.29$, ögretmen alt boyutunun $\bar{x}=7.70$, matematik alt boyutunun $\bar{x}=7.31$, okuma yazma alt boyutunun $\bar{x}=7.70$ olduğu görülmektedir. Elde edilen alt boyut puanlarının aritmetik ortalaması ve standart sapmasına bakılarak üç grup belirlenmiştir. Gruplar, ortalamanın 0.5 standart sapma altında kalanlar, ortalamanın 0.5 standart sapma altı ve üstü aralığında kalanlar ve ortalamanın 0.5 standart sapma üstünde kalanlar alınarak oluşturulmuştur. Bu gruplardan ilki düşük, ikincisi orta ve üçüncüsü de yüksek olarak adlandırılmış ve gruplar Tablo 4'te sunulmuştur. 
Tablo 4. Aritmetik Ortalama ve Standart Sapmaya Göre Oluşturulan Gruplar

\begin{tabular}{lllll}
\hline & Alt Boyutlar & Düşük & Orta & Yüksek \\
\hline \multirow{2}{*}{ Okul Hakkındaki } & Okul & 49 & 44 & 157 \\
Duygularım & Öğretmen & 39 & 45 & 166 \\
Ölçeği & Matematik & 63 & 125 & 62 \\
& Okuma yazma & 101 & 59 & 90 \\
\hline
\end{tabular}

Tablo 4 incelendiğinde çocukların okula ilişkin duygularının (okula gelme ve okulda yaptıklarını eğlenceli bulma vb.) 49'unun düşük, 44'ünün orta ve 157'sinin ise yüksek düzeyde olduğu belirlenmiştir. Çocukların öğretmenle ilgili düşüncelerinin (öğretmenin ilgisi ve öğretmeni sevme vb.) 39'unun düşük, 45’inin orta ve 166'sının ise yüksek düzeyde olduğu saptanmıştır. Çocukların matematik yeterliğine ilişkin algılarının (sayıları tanıma, sayılarla ilgili yeni şeyler öğrenmek isteme vb.) 63'ünün düşük, 125’inin orta ve 62'sinin ise yüksek düzeyde olduğu tespit edilmiştir. Çocukların okuma yazma yeterliliğine ilişkin algılarının (harfleri tanıma, harflerle ilgili yeni şeyler öğrenmek isteme vb.) 101'inin düşük, 59'unun orta ve 90'1nın ise yüksek düzeyde olduğu belirlenmiştir.

Çocukların cinsiyetine göre Okul Hakkındaki Duygularım Ölçeği alt boyut puanlarının farklılaşıp farklılaşmadığını belirlemeye yönelik yapılan t testi sonuçları Tablo 5’te verilmiştir.

Tablo 5. Cinsiyet Değişkenine Göre Okul Hakkındaki Duygularım Ölçeğinin Alt Boyut Puanlarına İlişkin t-Testi Sonuçları

\begin{tabular}{llcccccc}
\hline $\begin{array}{l}\text { Alt } \\
\text { Boyutlar }\end{array}$ & Cinsiyet & $\mathbf{n}$ & $\overline{\boldsymbol{x}}$ & $\mathbf{S D}$ & $\mathbf{t}$ & $\mathbf{d f}$ & $\mathbf{p}$ \\
\hline \multirow{3}{*}{ Okul } & K1z & 134 & 8.33 & 1.054 & .602 & 248 & .548 \\
& Erkek & 116 & 8.25 & 1.200 & & & \\
Öğretmen & K1z & 134 & 7.79 & 1.176 & 1.136 & 225.58 & .257 \\
& Erkek & 116 & 7.60 & 1.401 & & & \\
Matematik & K1z & 134 & 7.40 & 1.292 & 1.048 & 248 & .296 \\
Okuma & Erkek & 116 & 7.21 & 1.536 & & & \\
yazma & Erkek & 134 & 7.79 & 1.176 & 1.136 & 225.58 & .257 \\
\hline
\end{tabular}

* $\mathrm{p}>0.05$ 
Tablo 5 incelendiğinde, Okul Hakkındaki Duygularım Ölçeği, okul ( $\mathrm{t}=.602$, $\mathrm{p}<0.05)$, ögrretmen $(\mathrm{t}=1.136, \mathrm{p}<0.05)$, matematik $(\mathrm{t}=1.048, \mathrm{p}<0.05)$ ve okuma yazma $(t=1.136, p<0.05)$ alt boyut puanlarının cinsiyet değişkeni açısından anlamlı bir farklılık göstermediği görülmektedir.

\section{B. Nitel Bulgular}

Çocukların yarı yapılandırılmış görüşme formundaki okul ile ilgili sorulara verdikleri yanıtlar incelendiğinde, 6 çocuk kendini okulda iken biraz üzgün hissettiğini, 24 çocuk ise "mutlu, iyi ve neşeli" hissettiklerini ifade etmişlerdir. "İlk annemden ayrıldığımda üzgün hissediyorum. Sonra arkadaşımla oynadiğımda mutlu oluyorum (ç.15) Mutlu, iyi hissediyorum. Kendimi evde gibi hissediyorum (c.27)"

"En çok ne zaman böyle hissediyorsun?" sorusuna ise çocuklar oyun oynarken ve sanat ile müzik etkinliği yaparken mutlu hissettiklerini belirtmişlerdir.

"Okulda en çok ne yapmayı seviyorsun?" sorusuna, 10 çocuk bahçede oyun oynamayı, 15 çocuk oyun oynamayı, 3 çocuk müzik etkinliği, 16 çocuk ise sanat etkinliği yapmayı sevdiklerini belirtmişlerdir. Ayrıca 3 çocuk sayılarla ilgili etkinlik yapmayı, 1'er çocuk da deney yapmayı, satranç oynamayı ve İngilizce öğrenmeyi sevdiğini ifade etmiştir. "Bahçedeki kulübe evinde oyun oynamayı seviyorum (c.30). Arkadaşlarımla deney yapmayı seviyorum (ç.3). Sayılarla ilgili çalışmayı seviyorum. Öğretmen sayı gösterdiğinde lego getiriyorum (ç.13). Şarkı söylemeyi, dans etmeyi, parkta oynamayı seviyorum (c.8).”

“Öğretmenin hakkında ne hissediyorsun?” sorusuna çocukların verdiği yanıtlar incelendiğinde 27 çocuk öğretmenini çok sevdiğini belirtmiş, 2 çocuk iyi hissettiğini söylemiş, bir çocuk ise bilmiyorum yanıtını vermiştir. "Güzel bir şey hissediyorum. Öğretmenimi çok sevdiğimi hissediyorum (c..7). Seviyorum bizimle ilgileniyor. Benim annemmiş gibi hissediyorum (ç.27). İyi öğretmen. Bizi çalıştırmasını seviyorum (ç. 6).”

"Öğretmeninle en çok ne yapmayı seviyorsun?" sorusuna 13 çocuk sanat etkinliği, 6 çocuk Türkçe etkinliği, 5 çocuk oyun etkinliği, 5 çocuk müzik etkinliği, 1'er çocuk matematik etkinliği ve deney yapmayı sevdiklerini, 4 çocuk 
öğretmeninin ona destek olmasını sevdiğini, 5 çocuk ise öğretmenine sarılmayı ve onunla sohbet etmeyi sevdiğini belirtmiştir. "Boyama yapmayı, kesmeyi seviyorum (c.7). Sarilmayl, sohbet etmeyi seviyorum (c. 11). Oyuncak toplamamiza yardım etmesini seviyorum (c.12). Sohbet etmeyi, bize kitap okumasını seviyorum (ç. 13)."

"Sayılarla ilgili okulda neler yapıyorsun? En çok hangisini seviyorsun?" sorusuna 28 çocuk ritmik sayma yaptıklarını, 22 çocuk sayı yazma çalışmaları yaptıklarını, 12 çocuk birebir eşleştirme yaptıklarını, 4 çocuk sayı tanıma ve 1'er çocuk ise sayı ile ilgili şarkı söylediklerini ve işlem yaptıklarını belirtmiş, 1 çocuk ise bilmiyorum yanıtını vermiştir. "Sayıları sayıyoruz. Boş kâğıda sayıları yazıyoruz (c.1). Sayıları nesne ile birleştiriyoruz. 10 tane kuş var ikisi gitti (c..7). Spor yaparken sayı sayıyoruz (c.16). Sayılarla ilgili oyun oynamayı, oyuncakları sayma oyununu seviyorum (c.22).

"Harflerle ilgili okulda neler yapıyorsun? En çok hangisini seviyorsun?" sorusuna çocukların verdikleri yanıtlar incelendiğinde, 12 çocuk bilmiyorum yanıtını vermiş, 12 çocuk aynı sesle başlayan sözcük bulduklarını, 3 çocuk adlarını yazdıklarını, 2 çocuk harflerle ilgili şarkı söylediklerini, 1 çocuk ise okuma yazmaya hazırlık ile ilgili çalışma sayfası yaptıklarını belirtmiştir. "Harfleri öğreniyoruz. Şarkı söylüyoruz. Aynı sesle başlayan sözcükler buluyoruz sinıftaki eşyalardan (ç.22). Bazen sinıf içinde aynı sesle başlayan sözcükler buluyoruz (c.23). İsmimi yazmayı seviyorum (c.24). Bu harf ne ile başlarsa götür diyoruz (c.1).

\section{SONUÇ VE TARTIŞMA}

60-72 aylık çocukların okula ilişkin duyguları, öğretmene ilişkin düşünceleri ve akademik yeterliklerine ilişkin algılarını belirlemek amacıyla yapılan araştırmanın sonucunda elde edilen bulgular, çocukların okula ilişkin duygularının 49'unun düşük, 44'ünün orta ve 157'sinin yüksek düzeyde olduğunu göstermektedir. Görüşmelerde de 24 çocuk okulda kendini mutlu, iyi ve neşeli hissettiğini ifade etmiştir. Üzgün hisseden çocuklar ise annelerinden ayrıldıkları için kendilerini mutsuz hissettiklerini belirtmişlerdir. Bu sonuç; aileden ayrılan çocukların okula ilişkin olumsuz duygular geliştirmesine, başka bir söylemle çocuğun aileden ayrılma nedeni olarak okulu görmesine bağlı 
olarak, okula karş1 olumsuz bir alg1 oluşturduğu söylenebilir. Çocuğun okula ilişkin duygularında aile, öğretmen ve okul kritik bir öneme sahiptir. Okula uyum sürecinde aile, okulun sosyal, duygusal, akademik ve fiziksel beklentileri doğrultusunda çocuğa temel yaşamsal deneyimleri kazandırmakla yükümlüdür. Ayrıca ailenin okulla ilgili deneyimleri ve beklentileri doğrultusunda takındığı tutum ve aile içi iletişim de çocuğun okula uyumunu kolaylaştırmakta ya da zorlaştırmaktadır (McCubbins, 2004; İnal, 2010). Çocuğun okula karşı olan tutumunda çocuğun hazır oluşu kadar, çocuk ve ailesi için uygun deneyimleri sunabilmesi açısından okulun da çocuğa hazır olması gerekir (Spencer, 1999; Lam ve Pollard, 2006). Bununla birlikte, çocukların büyük çoğunluğu okulda oyun oynarken kendilerini mutlu hissettiklerini söylemişlerdir. Bu sonuç oyunun, çocukların okul ortamına uyum sağlama ve mutlu olmalarında önemli bir araç olduğunu göstermektedir. Oyun, çocukların sosyal iletişim kurmalarını desteklemekte, çocukların okula uyumlarını da kolaylaştırmaktadır.

Çocukların öğretmenle ilgili düşüncelerinin 39'unun düşük, 45’inin orta ve 166'sının ise yüksek düzeyde olduğu saptanmıştır. Yapılan araştırmalar öğretmen çocuk iletişiminin, çocukların okula uyumunda önemli etkisi olduğunu ortaya koymaktadır (Pianta, Steinberg ve Rollins, 1995; Birch ve Ladd, 1997; Pianta, Nimetz ve Bennett, 1997; Saft ve Pianta, 2001). Okul öncesi dönemde öğretmen ve çocuk ilişkisindeki yakınlık, çocukların bilişsel yetkinlik ve sosyal duygusal uyumunu olumlu yönde etkilerken, negatif bir tutum ise sonraki yıllardaki öğretmenleriyle olan ilişkilerini olumsuz etkilemekte ve çocuğun okula uyumunu da zorlaştırmaktadır (Pianta vd.,1995; Birch ve Ladd, 1997; Howes vd., 2000; Pianta ve Stuhlman, 2004). Çocuğun okula karş1 tutumu ve uyumu ile ilgili verilere bakıldığında, öğretmeniyle olan iletişiminde daha fazla çatışma yaşayan çocukların, sınıf ortamıyla daha az ilgilendikleri ve akademik başarılarının düşük olduğu; yakın ve destekleyici öğretmen tutumunun ise, okulda başarılı olma güçlüğü olan çocuklarda bile olumsuz sonucun ortaya çıkma riskini azalttığı ve çocukların okula karşı olumlu bir tutum geliştirmelerini sağladığı görülmektedir (Valeski ve Stipek, 2001; Pianta ve Stuhlman, 2004). Nitel veriler incelendiğinde de çocukların öğretmenlerini sevdiklerini ifade ettiği görülmektedir. Bu bulgu doğrultusunda çalışma 
grubunda yer alan çocukların, öğretmenleriyle iletişiminin olumlu olduğu söylenebilir.

Okul öncesi dönemde yer alan okuma yazma becerileri ve matematik becerileri erken akademik beceriler olarak adlandırılmaktadır. Çocukların akademik becerileri kazanması öğretmenleriyle kurduğu iletişimle ilişkilidir (Uyanık ve Kandir, 2010).

Öğretmen ile kurulan olumlu iletişim ve çocuğun duygusal açıdan kendini güvende hissetmesi, dikkatini öğrenmeye odaklamasını sağlamakta, buna bağl1 olarak da akademik becerisi artmaktadır (Burchinal vd., 2002). Diğer yandan yapılan çalışmalar, akademik açıdan başarılı olan okul öncesi ve birinci sınıftaki çocukların okullarını daha fazla sevdikleri ve öğretmenleri ile akademik açıdan daha başarısız olan sınıf arkadaşlarına göre daha iyi iletişime sahip olduklarını göstermektedir (Ramey vd., 1998; Ladd vd., 1999). Araştırmanın nicel verileri, çocukların matematiğe ilişkin 63'ünün düşük, 125'inin orta ve 62'sinin ise yüksek düzey, okuma yazmaya ilişkin 101'inin düşük, 59'unun orta ve 90'ının yüksek düzeyde algısı olduğunu göstermektedir. Nicel verilerde, çocukların okula ilişkin duygularının ve öğretmene ilişkin düşüncelerinin yüksek olmasına rağmen, matematik ve okuma yazma yeterliğine ilişkin algılarının düşük ve orta düzeyde olması dikkat çekici bir bulgudur. Bu durum, nitel verilerden elde edilen bulgularla, hem matematik hem de okuma yazmaya hazırlık etkinliklerinin nitelik ve çeşitlilik açısından eksik kaldığı şeklinde yorumlanabilir.

Cinsiyet değişkeni açısından, ölçeğin alt boyutlarına ilişkin puanların anlamlı bir farklılık göstermediği görülmektedir. Bu bulguyu destekleyen araştırmaların (Çıkrıkçı, 1999; Yoleri, 2014) yanı sıra, okula uyum ve okul başarısı açısından kız çocuklarının lehine anlamlı sonuçlar ortaya koyan araştırmalar da bulunmaktadır (Ramey vd., 1998; Howes vd.,2000; Wang, Chen, Sorrentino ve Szeto, 2008). Öğretmen-çocuk iletişimiyle ilgili yapılan çalışmalarda, öğretmen ve gözlemci değerlendirmeleri sonucu, cinsiyete göre erkek çocukların kız çocuklara göre öğretmenleriyle daha fazla çatışmalı ve daha az yakın ilişki yaşadıkları görülürken (Birch ve Ladd, 1997; Kesner, 2000; Saft ve Pianta, 2001; Stuhlman ve Pianta, 2001; Murray vd., 2008), çocuk gözüyle yapılan araştırmalarda ise anlamlı bir farklılaşma görülmemiştir (Mantzicopoulos ve 
Neuharth-Pritchett, 2003). Çocukların akademik becerilerine ilişkin algılarının da cinsiyet değişkenine göre farklılaşmadığı sonucuna ulaşılmıştır. Alan yazın incelendiğinde çocukların algılarının cinsiyete göre değişip değişmediği ile ilgili tutarsız araştırma bulguları tespit edilmiştir (Cole, Martin, Peeke, Seroczynski ve Fier, 1999; Eccles vd. 1993; Marsh, Walker, Debus, 1991; Ramey vd., 1998; Valeski ve Stipek, 2001).

Çalışmanın bulguları doğrultusunda, okula uyum sürecinde çocukların ayrılık kaygılarına ilişkin, okulun gerekli desteği aile ve çocuğa sağlaması gerektiği söylenebilir. Çocukların okula uyum sürecini daha kolay atlatabilmesi için özellikle oyun etkinliklerinden yararlanılabilir. Bununla birlikte erken akademik becerilere ilişkin algılarını olumlu yönde geliştirmek için matematik ve okuma yazma etkinliklerinin niteliğinin artırılması ve çeşitlilik açısından zenginleştirilmesi gerektiği söylenebilir. Bundan sonra yapılacak araştırmalarda; okula, öğretmene ve akademik yeterliklerine ilişkin çocuk bakış açısını ortaya koymaya yönelik farklı örneklemlerde, farklı veri toplama yöntemlerinin kullanıldığı çalışmalar yapılabilir. Ayrıca hem öğretmenden hem de çocuktan toplanılacak veriler karşılaştırılabilir.

\section{KAYNAKÇA}

BIRCH, S. H., \& LADD, G. W. (1997). The teacher-child relationship and children's early school adjustment. Journal of School Psychology, 35(1), 61-79.

BRONFENBRENNER, U., \& MORRIS, P.A. (2006). The ecology of developmental processes. In W. Damon and R.M. Lerner (Eds.), Handbook of child psychology: Vol. 1: Theoretical models of human development, 6th Edition (pp. 993-1028). Hoboken, NJ: John Wiley \& Sons.

BURCHINAL, M. R., PEISNER-FEINBERG, E., PIANTA, R., \& HOWES, C. (2002). Development of academic skills from preschool through second grade: Family and classroom predictors of developmental trajectories. Journal of School Psychology, 4O(5), 415-436.

COlE, D. A., MARTIN, J. M., PEEKE, L. A., SEROCZYNSKI, A. D., \& FIER, J. (1999), Children's over- and underestimation of academic competence: a longitudinal study of gender differences, depression, and anxiety. Child Development, 70(2), 459-473. doi:10.1111/1467-8624.00033.

ÇIKRIKÇI, S. (1999). Ankara il merkezinde resmi banka anaokullarina devam eden 5-6 yaş çocuklarinın okul olgunluğu ile aile tutumu arasındaki ilişskinin incelenmesi, Gazi Üniversitesi Sosyal Bilimler Enstitüsü, Ankara. 
DOTTERER, A. M., \& LOWE, K. (2011). Classroom context, school engagement, and academic achievement in early adolescence. Journal of Youth and Adolescence, 40(12), 1649-1660. doi: 10.1007/s10964-011-9647-5.

ECCLES, J., WIGFIELD, A., HAROLD, R. D., \& BLUMENFELD, P. (1993). Age and gender differences in children's self and task perceptions during elementary school. Child development, 64(3), 830-847.

EKİNCI-VURAL, D. (2006). Okul öncesi eğitim programındaki duyuşsal ve sosyal becerilere yönelik hedeflere uygun olarak hazırlanan aile katılımlı sosyal beceri eğitimi programının çocuklarda sosyal becerilerin gelişimine etkisi. Yayınlanmamış Yüksek Lisans Tezi, Dokuz Eylül Üniversitesi Eğitim Bilimleri Enstitüsü, İzmir.

FABIAN, H. (2000). Small steps to starting school. International Journal of Early Years Education, 8(2), 141-153, doi: 10.1080/09669760050046183.

GREEN, J. C., KRAYDER, H., \& MAYER, E. (2005). Combining qualitative and quantitative methods in social inquiry. In B. Somekh \& C. Lewin (Eds.). Research methods in the social sciences (pp. 275-282). London: Sage.

GREGORIADIS, A., \& GRAMMATIKOPOULOS, V. (2013). Teacher-child relationship quality in early childhood education: The importance of relationship patterns. Early Child Development and Care 184(3), 386-402. doi:10.1080/03004430.2013.790383.

HARRISON, L. J., CLARKE, L., \& UNGERER, J. A. (2007). Children's drawings provide a new perspective on teacher-child relationship quality and school adjustment. Early Childhood Research Quarterly, 22(1), 55-71.doi: 10.1016/j.ecresq.2006.10.003.

HOWES, C., PHILliPSEN, L., \& PEISNER-FEINBERG, E. (2000). The consistency and predictability of teacher-child relationships during the transition to kindergarten. Journal of School Psychology, 38(2), 113-132.

HUGHES J. N., \& KWOK, O. (2006). Classroom engagement mediates the effect of teacherstudent support on elementary students' peer acceptance: A prospective analysis. Journal of School Psychology, 43 (6), 465-480.

HUGHES, J. N., \& KWOK, O. (2007). Influence of student-teacher and parent-teacher relationships on lower achieving readers' engagement and achievement in the primary grades. Journal of Educational Psychology, 99(1), 39-51. http:/ /doi.org/10.1037/0022-0663.99.1.39.

İNAL, G. (2010). Okula başlama ve uyum süreci. Alisinanoğlu, F. (Ed.), İlköğretime hazırlık ve ilköğretim programları (ss. 87-109). İstanbul: Matsis.

KARACA, N. H., GÜNDÜZ, A., \& ARAL, N. (2011). Okul öncesi dönem çocuklarının sosyal davranışının incelenmesi. Kuramsal Eğitimbilim Dergisi, 4(2). 65-76.

KESNER, J. E. (2000). Teacher characteristics and the quality of child-teacher relationships. Journal of School Psychology, 38(2), 133-149. doi:10.1016/S00224405(99)00043-6.

KOOMEN, H. M. Y., VERSCHUEREN, K., \& THIJS, J. T. (2006). Assessing aspects of the teacherchild relationship: A critical ingredient of a practice-oriented psychodiagnostic approach. Educational and Child Psychology, 23(3), 50-60.

LADD, G. W., BIRCH, E. S., \& BUHS, E. (1999). Children's social and scholastic lives in kindergarten: Related spheres of influence? Child Development, 70, 1373-1400.

LADD, G.W., BUHS, E. S., \& SEID, M. (2000). Childrens initial sentiments about kindergarten: Is school liking an antecedent of early classroom participation and achievement? Merrill-Palmer Quarterly, 46(2), 255-279.

LADD, G.W., HERALD, S.L., \& KOCHEL, K.P. (2006). School readiness: Are there social prerequisites? Early Education \& Development, 17 (1), 115-150. doi: http://dx.doi.org/10.1207/s15566935eed1701_6.

LAM, M. S., \& POLLARD, A. (2006). A conceptual framework for understanding children as agents in the transition from home to kindergarten. Early Years, 26(2), 123-141. 
MANTZICOPOULOS, P. \& NEUHARTH-PRITCHETT, S. (2003). Development and validation of a measure to assess head start children's appraisals of teacher support. Journal of School Psychology, 41(6):431-451.

MARSH, H. W., WALKER, R., \& DEBUS, R. (1991). Subject-specific components of academic self-concept and self-efficacy. Contemporary Educational Psychology, 16(4), 331-345. doi: https://doi.org/10.1016/0361-476X(91)90013-B

MCCUBBINS, J. L. (2004). Transition into kindergarten: A collaboration of family and educational perspectives. Unpublished master's thesis, Virginia Polytechnic Institute and State University, Blacksburg, Virginia.

MEŞECİ, F. (2008). Öğretmenin sosyalleştirici rolü ve istenmeyen davranışlarla başa çıkma. Hasan Ali Yücel Eğitim Fakültesi Dergisi, 5(1), 115-125. [Çevrim-içi: http://dergipark.gov.tr/iuhayefd/issue/8790/109882] Erişim Tarihi: 14 Nisan 2017.

MURRAY, C., MURRAY, K. M., \& WAAS G. A. (2008). Child and teacher reports of teacherstudent relationships: Concordance of perspectives and associations with school adjustment in urban kindergarten classrooms. Journal of Applied Developmental Psychology, 29(1), 49-61. doi: https://doi.org/10.1016/j.appdev.2007.10.006.

PIANTA, R., NIMETZ, S.L., \& BENNETT, E. (1997). Mother-child relationships, teacherchild relationships, and school outcomes in preschool and kindergarten. Early Childhood Research Quarterly, 12 (3), 263-280. doi: https://doi.org/10.1016/S0885-2006(97)90003-X.

PIANTA, R.C., STEINBERG, M.S., \& ROLLINS, K. (1995). The first two years of school: Teacher-child relationships and deflections in children's classroom adjustment. Development \& Psychopathology, 7(2), 295-312. doi: https://doi.org/10.1017/S0954579400006519.

PIANTA, R. C., \& STUHLMAN, M. W. (2004). Teacher-child relationships and children's success in the first years of school. School Psychology Review, 33 (3), 444-458.

RAMEY, S., LANZI, R., PHILLIPS, M., \& RAMEY, C. (1998). Perspectives of former Head Start children and their parents on the transition to school. Elementary School Journal, 98, 311-327.

SAFT, E. W., \& PIANTA, R.C. (2001). Teacher's perceptions of their relationships with students: Relations with child and teacher characteristics. School Psychology Quarterly, 16(2),125-141. doi: http://dx.doi.org/10.1521/scpq.16.2.125.18698

SPENCER, M. B. (1999). Social and cultural influences on school adjustment: The application of an identity-focused cultural ecological perspective. Educational Psychologist, 34(1), 42-57.

STIPEK, D., FEILER, R., DANIELS, D., \& MILBURN, S. (1995). Effects of different instructional approaches on young children's achievement and motivation. Child Development, 66, 209-223.

STIPEK, D. (2001). Pathways to constructive behavior: Importance of academic achievement in the early elementary grades. In A. Bohart \& D. Stipek (Eds.), Constructive and destructive behavior: Implications for family, school and society. Washington, DC: American Psychological Association.

STUHLMAN, M. W., \& PIANTA, R. C. (2001). Teachers' narratives about their relationships with children: Associations with behavior in classrooms. School Psychology Review, 31 (2), 148-163.

UYANIK, Ö., \& KANDIR, A. (2010). Okul öncesi dönemde erken akademik beceriler. Kuramsal Eğitimbilim, 3(2), 118-124.

UZ BAŞ, A. (2003). İköğretim 4. ve 5. sinufta okuyan öğrencilerin sosyal becerileri ve okul uyumu ile depresyon düzeyleri arasındaki iliş̧kinin incelenmesi. Yayınlanmamış Yüksek Lisans Tezi, Dokuz Eylül Üniversitesi Eğitim Bilimleri Enstitüsü, İzmir. 
VALESKI, T., \& STIPEK, D. (2001). Young Children's Feelings about School. Child Development, 72(4), 1198-1213.

WANG, Z., CHEN, X., SORRENTINO, R., \& SZETO, A. C. (2008). Uncertainty orientation in Chinese children: Relations with school and psychological adjustment. International Journal of Behavioral Development, 32 (2), 137-144. doi: $10.1177 / 0165025407087212$.

YOLERİ, S. (2014). The effects of age, gender, and temperament traits on school adjustment for preschool children. E-International Journal of Educational Research, 5(2), 54-66.

YILDIRIM, A., \& ŞİMŞEK, H. (2004). Sosyal bilimlerde nitel araştırma yöntemleri, Ankara: Seçkin Yayıncılik.

YURDUGÜL H. (2005). Ölçek geliştirme çalışmalarında kapsam geçerliği için kapsam geçerlik indekslerinin kullanılması. In: XIV. Eğitim Bilimleri Kurultayı; 28-30; Pamukkale Üniversitesi, Denizli; 2005. s.1-6. [Çevrim-içi: http://yunus.hacettepe.edu.tr/ yurdugul/3/indir/PamukkaleBildiri.pdf ] Erişim Tarihi: 17 Nisan 2017. 